Научная статья

УДК 811.161.1: 81'374

DOI 10.18101/2686-7095-2021-3-103-106

\title{
В ЗАЩИТУ ЭТНОНИМА ГУРАН
}

\section{(C) Крючкова Любовь Леонидовна}

кандидат филологических наук, доцент,

Благовещенский государственный педагогический университет

Россия, 675000, г. Благовещенск, ул. Ленина, 104

1lkr@mail.ru

\begin{abstract}
Аннотация. В «Русском этимологическом словаре» А. Е. Аникина имеется словарная статья гуран, в которой категорически отвергается этимология слова, изложенная Л. Л. Крючковой в монографии «Словарные материалы Г. С. Новикова-Даурского как источник для русской исторической лексикографии», где утверждалось, что первоначально слово гуран появилось как этноним. История слова связывалась с пекинскими, или албазинскими, казаками, которые служили в знаменной роте в Пекине. После реформирования китайской армии какая-то часть этих казаков вернулась в Забайкалье. Они и привезли слово гурун, которое в гольдском (нанайском) и в маньчжурском языках употреблялось в значении 'люди, народ'. От них казаки могли слышать это слово и сделали его самоназванием. Слово гуран - результат смешения гольдского и маньчжурского гурун с неясно произносимым звуком $y$, которое стало звучать как гуран под влиянием более известного у русских, употреблявшегося в значении 'дикий козел, самец косули'.
\end{abstract}

Ключевые слова: гуран, гурун, этимология, этноним, прозвище, нанайский (гольдский) язык, маньчжурский язык.

\section{Для цитирования}

Крючкова Л. Л. В защиту этнонима гуран // Вестник Бурятского государственного университета. Филология. 2021. Вып. 3. С. 103-106.

В «Этимологическом словаре русского языка» А. Е. Аникина имеется словарная статья гуран, в которой оно дается как прозвище прибайкальского старожила. О том, что оно не может быть этнонимом, объясняется географией происхождения слова»: прозвище возникло в Прибайкалье, где нет нанайцев» [Аникин, 2018, вып. 12, с. 251]. Несмотря на то что этимология Л. Л. Крючковой А. Е. Аникиным отвергнута, мы продолжаем ее отстаивать.

Наше исследование подробно изложено в монографии «Словарные материалы Г. С. Новикова-Даурского как источник для русской исторической лексикографии» (Благовещенск 2015), в которой утверждается гипотеза: гуран - это этноним и прозвище.

Все существующие гипотезы основаны на том, что гуран - прозвище казаков. В монографии они подробно описаны. В данной статье мы ограничимся их перечислением:

1) исходное бранное значение слова гуран происходит будто бы от того, что казаки-старожилы носили шапки из гурана [Майоров, Болсохоева, 1995, с. 71]; 2) «метисное население», появившееся в результате «брачных контактов русских казаков с бурятками и тунгусками» [Коваленко, 2008, с. 53; Давыдова, 1998, с. 29]; 3) будто бы на территории Забайкалья в войсках Чингисхана служили урраны [Куликов, 1996, с. 7]; 
4) пошло от того, что казак на охоте подстрелил своего приятеля, приняв его за козла» [Энциклопедия казачества, 1992, с. 94]; 5) появление значения казак обусловлено паронимической аттракцией, то есть совпадением начальных слогов у слов козел и казак [цит. по: Аникин, 2000, с. 172].

Перечисленные нами гипотезы не учитывают время появления слова гуран. Мы обратили внимание, что впервые оно зафиксировано в Читинской губернии Н. А. Ноневичем в 1895 г., а в начале XX - амурским краеведом Г. С. Новиковым-Даурским, преподавателем ДГУ А. П. Георгиевским, организовавшим экспедиции в Забайкалье в 1929 г. В «Словаре русских народных говоров» запись датирована 1916 г. ${ }^{1}$ До этого времени как в литературе о Сибири, так и в словаре В. И. Даля оно отсутствовало, хотя слово гуран в значении ‘дикий козел’ существовало.

Перед нами стояло три вопроса: 1) почему слово гуран появилось только в 1895 г.; 2) почему оно было связано с казаками; 3) почему его первая фиксация относится к Забайкалью. Эти вопросы стали ключевыми в поисках истории слова.

Статья Л. Ульяницкого, в 1909 г. лично исследовавшего этническую группу, известную как албазинские, или пекинские, казаки, навела на мысль о том, что они имеют прямое отношение к этнониму гуран. Нет смысла пересказывать еще раз о том, что писал Л. Ульяницкий [Ульяницкий, 1912, с. 67-93]. Остановимся на нескольких важных моментах:

1. После падения крепости Албазин в 1681 г. 45 (по другим данным - 42) казаков оказались в Китае (Маньчжурии), где стали нести службу в Пекине в знаменной роте при императоре. Им были выданы жены из так называемого разбойничьего приказа, то есть преступницы. С течением времени сложился вполне определенный чистый тип этнической группы, которую называли пекинцами: монгольский с некоторыми чертами русского типа. Л. Ульяницкий отмечал только один случай, когда китаец женился на албазинке.

2. Какая-то часть казаков неплохо устроилась в Пекине и вполне растворилась среди китайцев, а какая-то часть вернулась на родину, в Забайкалье (именно оттуда началось продвижение русских на восток, окончившееся неудачей). В монографии не были указаны причины их возвращения, так как не хватало источников. Позднее нам удалось познакомиться с небольшим исследованием В. Н. Кондратьева «Современный Китай», изданным в Благовещенске в 1908 г. Он, в частности, писал о реформировании китайской армии в конце XIX в. После упразднения знаменной роты надобность в службе пекинских казаков отпала. Это и стало, как мы предполагаем, причиной их появления в Забайкалье. Ничего не умевшие делать, кроме службы, они оказались в рядах забайкальских казаков. Вот почему 1895 год - первая фиксация слова гуран!

Названный нами источник позволяет установить, что гураны - самостоятельная этническая группа, а гуран - это их самоназвание, «привезенное» в Забайкалье. Откуда оно могло появиться? Мы установили, что в гольдском (нанайском) языке было слово гуру́н 'люди, народ' [Протодьяконов, 1901, с. 11]. После того как была написана монография, нам удалось найти слово гуру́нъ 'государство, царствующая династия (народ, нация)' в маньчжурском языке [Захаров, 1875, с. 364], еще функционировавшем в XIX в. Новый источник дополняет наше предположение: это слово пекинцы могли слышать как от нанайцев, так и от маньчжуров, населявших СеверС. 237.

${ }^{1}$ Словарь русских народных говоров. Ленинград: Наука. Ленингр. отделение, 1979. Вып. 7. 
ный Китай. Гольдский язык, как известно, принадлежит к тунгусо-маньчжурской ветви языков. Так что противоречия здесь нет. Под влиянием бурятского слова гуран 'дикий козел, самец козули', бывшего в активном употреблении у русских, оно стало произноситься также. Почему же оно стало прозвищем, а не осталось этнонимом? Главная причина, по нашему мнению, заключается в том, что пекинцы не могли составлять большинства жителей этих мест, поэтому в народе сложилось представление о том, что гураны - казаки Забайкалья, и гуран - их прозвище.

О последнем аргументе в пользу того, что гуран - этноним, свидетельствует тот факт, что это значение сохранилось в языковом сознании жителей Приамурья переселенцев из Забайкалья. Приведем примеры. При знакомстве с одной из семей:

- Вы из Забайкалья?

- Да. А откуда Вы узнали?

- Я больше скажу. Вы гураны.

- Да, мы гураны. А как Вы узнали?

- Таня, в Вашей внешности есть что-то азиатское.

- Да? У меня родители русские. А-а, вспомнила: у меня бабушка была гуранка.

- У меня славянских корней намешано много: русские, украинцы, белорусы, поляки.

- А у меня бабушка была гуранка, а дедушка - немец.

Таким образом, мы продолжаем утверждать, что слово гуран, впервые отмеченное в 1895 г., появилось как этноним. Оно связано с историей албазинских, или пекинских, казаков. Слово Гурун в значении ‘люди, народ’ было в гольдском (нанайском) и маньчжурском языках. Пекинцы могли его слышать от гольдов (нанайцев) и от маньчжуров, населявших Северный Китай. Ставшее их самоназванием, слово было «привезено» в Забайкалье. Под влиянием бурятского слова гуран 'дикий козел, самец козули', бывшего в активном употреблении у русских, оно стало произноситься также. Пекинцы не могли составлять большинства жителей этих мест, поэтому в народе сложилось представление о том, что гураны — прозвище казаков Забайкалья.

\section{Литература}

1. Аникин А. Е. Этимологический словарь русских диалектов Сибири: заимствования из уральских, алтайских и палеоазиатских языков. Москва; Новосибирск: Наука. Сибирское отделение, 2000. 768 с. Текст: непосредственный.

2. Аникин А. Е. Русский этимологический словарь. Вып. 12. Москва: Изд-во Ин-та рус. яз. им. В. В. Виноградова РАН; Новосибирск: Изд-во Ин-та филологии Сибирского отделения РАН; Санкт-Петербург: Нестор-История, 2018. 376 с. Текст: непосредственный.

3. Гольдско-русский словарь священника о. Прокопия Протодьяконова. Владивосток: Народная типография товарищества Сущинский и Кㅇ 1901.74 с. Текст: непосредственный.

4. Захаров И. И. Полный маньчжурско-русский словарь. Санкт-Петербург: Типография императорской академии, 1875. 1233 с. Текст: непосредственный.

5. Коваленко А. И. Культура казачества восточных окраин России (XVII - нач. XX в.). Благовещенск: Дальневосточное отделение Российской академии наук, 2008. 208 с. Текст: непосредственный.

6. Кондратьев В. Н. Современный Китай. Благовещенск: Кн. маг. Бутряков, 1908. 43 с. Текст: непосредственный.

7. Крючкова Л. Л. Словарные материалы Г. С. Новикова-Даурского как источник для русской исторической лексикографии. Благовещенск, 2015. 328 с. Текст: непосредственный. 
8. Куликов Е. Кто такие гураны? // Забайкальский рабочий. 1996. № 18. 27 янв. С. 7. Текст: непосредственный.

9. Майоров А. П., Болсохоева А. Д. Русские народные говоры Забайкалья. УланУдэ: Изд-во Бурят. гос. ун-та, 1995. С. 63-100. Текст: непосредственный.

10. Ульяницкий Л. Албазин и албазинца // Записки Приамурского отдела императорского общества востоковедения. Владивосток: Тип. канцелярии Приамурского Генерал-Губернатора, 1912. Вып. 1. С. 67-93.

11. Энциклопедия казачества / авторы-составители А. И. Скрылов, Г. В. Губарев. Москва: Вече, 1992. 544 с.

Статья поступила в редакцию 19.09.2021; одобрена после рецензирования 15.10.2021; принята к публикации 29.10.2021.

\title{
IN DEFENCE OF THE ETHNONYM ГУPAH 'GURAN'
}

\author{
Lubov L. Kruchkova \\ Cand. Sci. (Phil.), A/Prof. of Philological Education Department, \\ Blagoveshchensk State Pedagogical University \\ 104 Lenina St., Blagoveshchensk 675000, Russia \\ llkr.@mail.ru
}

Abstract. In Aleksandr Anikin's "Russian Etymological Dictionary" there is a dictionary entry гуран 'guran', which categorically rejects the etymology of the word, set forth by Lubov Kryuchkova in the monograph "Dictionary Materials by G. S. Novikov-Daursky as a Source for Russian Historical Lexicography". We argue that initially the word гуран 'guran' appeared as an ethnonym. The history of the word was associated with Beijing, or Albazin, Cossacks, who served in the colour company in Beijing. After the reform of the Chinese army, some of these Cossacks returned to Transbaikalia. They brought the word гурун 'gurun', which in the Goldic (Nanai) and Manchu languages was used to mean 'people'. The Cossacks could hear this word from them and then made it a self-name. The word гуран 'guran' is the result of a mixture of the Goldic and Manchu гурун 'gurun' with an unclearly pronounced sound [u], which began to sound like 'guran' under the influence of a more well-known word among the Russians, denoting 'a wild goat, male roe deer'.

Keywords: гуран 'guran', гурун 'gurun', etymology, ethnonym, nickname, the Nanai (Goldic) language, the Manchu language.

For citation

Kruchkova L. L. In Defence of the Ethnonym гуран 'guran'. Bulletin of Buryat State University. Philology. 2021; 3: 103-106 (In Russ.).

The article was submitted 19.09.2021; approved after reviewing 15.10.2021; accepted for publication 29.10.2021. 